\title{
PERSPECTIVES IN TEACHING NEGOTIATION SKILLS TO BUSINESS STUDENTS
}

\author{
Elena CIORTESCU ${ }^{\text {a* }}$ \\ a) Alexandru Ioan Cuza University, Faculty of Economics and Business \\ Administration, Iași, Romania
}

Please cite this article as:

Article History:

Ciortescu, E., 2019. Perspectives in teaching Received: 10 October 2019 negotiation skills to business students. Review of Accepted: 16 November 2019 Economic Studies and Research Virgil Madgearu, 12(2), pp.39-52.

doi: 10.24193/RVM.2019.12.38.

Abstract: The aim of this paper is to identify, discuss and find solutions to the major challenges which occur in the process of teaching negotiation skills, given the particular aspects which define the current context of higher education in the field of economics and business. By what means, to which extent and what challenges Business English teachers come across while trying to enable their students acquire these skills will be debated in the following parts of this paper. The first part of the paper will provide a definition of the term "negotiation" as well as an introduction in the current educational context at the Faculty of Economics and Business Administration, "Alexandru Ioan Cuza" University, Iasi, Romania. The second part of the paper will identify and discuss the major challenges which occur in the process of teaching ESP and BE, in general, and in negotiations, in particular. Finally, a practical example of how our purpose could be achieved will be provided in the third part.

Key words: business; economics; education; negotiations

JEL Classification: $A 1 ; A 2 ; A 3 ; Y 8$

(C) 2019 Alma Mater Publishing House. All rights reserved.

* Corresponding author. E-mail address: crismonais@yahoo.com. 


\section{References:}

1. Boone, L.E. and Kurtz, D.L., 1994. Contemporary Business Communication. USA: Prentice Hall, Inc.

2. Gibson, R., 2018. Working Effectively across Cultures. Business Spotlight, 7, pp.28-31.

3. Hochsieder, A., 2014. Making Polite Requests. Business Spotlight, $5, \mathrm{p} .45$.

4. Hogan, M., 2014. Reaching Agreement. Business Spotlight, 1, pp.46-47.

5. MacMillan English Dictionary for Advanced Learners, 2006. MacMillan.

6. Taylor, K., 2011. Asking Questions. Business Spotlight, 6, p.46.

7. Wahlandt, F., 2017. Interview with Ken Taylor. Negotiating with International Sales Partners. Business Spotlight, 3, pp.48-49.

8. http://en.wikipedia.org/wiki/Soft_skills [Accessed 10 September 2019].

9. https://www.businessphrases.net/hard-skills-list/ [Accessed 10 September 2019]. 